\title{
THE RELATIONSHIP BETWEEN HUMAN CAPITAL AND DIRECTORS' REMUNERATION OF MALAYSIAN PUBLIC LISTED COMPANIES
}

\author{
Nik Mohd Naqiuddin Nik Ahmad \\ Universiti Teknologi MARA \\ Anuar Nawawi \\ Universiti Teknologi MARA \\ Ahmad Saiful Azlin Puteh Salin* \\ Universiti Teknologi MARA
}

\begin{abstract}
A lot of previous study on directors' remuneration unable to find conclusive evidence of what are the determinants of directors' remuneration. Beside, many studies also fail to documented evidence on the relationship between directors' remuneration with corporate performance. Due to this, this study tries to examine the determinants of directors' remuneration from the human capital perspectives. Age, tenure and qualification were selected to test whether these factors contribute to the level of remuneration paid to the directors. Based on Malaysian listed companies, an ordinary least square regression analysis was employed to determine the predicted relationship. It was found that only age and tenure have significant positive relationship with total remuneration. This implicates that human capital elements do contribute to the amount of remuneration paid to the top executive of the company. This outcome also implies that the company may pay their directors based on the individual characteristics and background which possibly the reason of the existence of pay-for-performance non-relationship.
\end{abstract}

Keywords: Human Capital; Directors’ Remuneration; Age; Tenure; Qualification.

\section{INTRODUCTION}

The study related to directors' remuneration can be found across many numbers of disciplines, such as accounting, finance, economics, law, organizational behaviour, industrial relations and management. According to Hallock and Murphy (1999) there are many research papers published in related to directors' remuneration from 1995's

\footnotetext{
"Corresponding author: Ahmad Saiful Azlin Puteh Salin. Faculty of Accountancy, Universiti Teknologi MARA Perak, Seri Iskandar Campus, 32610 Seri Iskandar, Perak, Malaysia. +605-406 7000. ahmad577@perak.uitm.edu.my/saifulazlin@yahoo.com
} 
onwards due to the trend of separation of ownership and control in modern corporation and general acceptance of agency theory. With most of the studies focus to relate director's remuneration and corporate performance since early 1960s till now (Marris, 1963; Williamson, 1964; Gregg et. al., 1993; Conyon and Leech, 1994; Eriksson, 2000; Conyon and He, 2011) many studies examined the link between director's remuneration with human capital attributes such as age, qualification and tenure.

Although many studies exploring the relationship between pay and performance have found robust relationship between salary and size (Mehran, 1995; Yermack, 1995; Cheng and Firth, 2006; Ghosh, 2006), only a few have documented a pronounce link between performance related pay and long-term performance such as shareholder return. As a result, questions arise as to the organizations competence in linking pay to performance. This is possibly due to the root of the agency problem that resides with the board. In theory, board's function is to serve not only as a representative for shareholders, but also as a control mechanism for aligning the interest between the shareholders and executive (Fama, 1980; Beatty and Zajac, 1994). This premise may be undermined by directors capacity to influence the board (Eisenhardt, 1989) and hence the pay setting process in determining the appropriate remuneration.

Malaysia is also no exception. The level of directors' remuneration received in Malaysia has attracts high attention from Malaysian public and prospective investor. Some of companies are small in size but the remuneration packages offer to the directors is much higher than others. These companies argued that higher remuneration pay to directors to reduce the brain drain and prevent directors to serve in other countries like in the Middle East, China and the ASEAN region.

Based on this premise, it is believed that human capital element such as age, tenure and qualification able to influence the remuneration package received by the directors. For example, through increased tenure the directors can build a proven track record and develop new relationships with key individuals both within and outside the organization. Hence, the directors may gain control over the pay setting process and in turn design remuneration schemes based on their preferences.

Besides, in the current fast moving environment, the success of any nation generally and company particularly is highly depends on their human capital stock. Human capital theory suggest that education or training raises the productivity of workers by imparting useful knowledge and skills, consequently raising workers' future income by increasing their lifetime earnings (Becker,1964). Human capital theory rests on the assumption that formal education is highly instrumental and necessary to improve the productive capacity of people. In addition, human capital theory argues that differences in levels of education and skills gained by persons influence different level of wages. 
In the context of Malaysia, the government emphasize on human capital development, particularly through training and education. This is translated in the form of yearly national budget, in which significant amount of government expenditure was allocated for human capital. For example in Malaysia Budget 2012, RM 50.2 billion was allocated respectively for education sector in Malaysia. The amount has increase significantly in 2013, to RM67 billion. The government view education as the pillar of civilisation and the foundation of excellent. In order to achieve the aspiration of becoming a developed and high-income country, Malaysian government give priority to the development of education system to produce talented, highly skilled, creative and innovative workforce.

Due to this, it is argued that directors' remuneration also should be in line with directors' human capital characteristics. According to Malaysian Code of Corporate Governance (MCCG) (Finance Committee on Corporate Governance, 2001), directors' remuneration packages should be attractive to attract directors with huge experience and expertise. This code also requires directors to receive further training from time to time, particularly on relevant new laws and regulations and changing commercial risks. It is therefore expected that such emphasis on human capital attributes would have an effect on the directors' remuneration.

The objective of this study is then to examine the impact of key human capital attributes namely age, qualification and tenure of directors on the level of directors' remuneration in Malaysia listed company. This study contributes in certain number of ways.

First, this study explores the relationship between human capital attributes and directors' remuneration. The current literature does not explore much of this area, especially in the developing country like Malaysia. Most of the studies were conducted in the US and UK (Ingham and Thomson, 1995; McKnight and Tomkins, 2004). This study becomes among the pioneer study on the link between human capital attributes and directors' remuneration in Malaysia.

Second, this study uses human capital theory as main theory to explain the directors' remuneration in contrast of many other studies that used agency theory. Based on human capital theory, differences in levels of education and skills gained by persons will affect their wages. The findings of the study will identify the key elements that differentiate level of remuneration package received by directors.

Third, the findings of this study also will benefit the shareholders in evaluating level of remuneration package received by respective directors. They will be able to determine whether the remuneration received by directors of company compatible with their age, qualification and tenure. Practically, the findings of the study should shed light to the policy makers and business practitioners on the importance of human capital attributes in determining directors' pay level. 
Finally, from academic point of view, this study will add to the body of literature on the level of executive compensation practice in Malaysian environment and from the human capital theory perspectives. This paper is organised as follows. Next section is review of literature followed with research method. Section four is findings and discussions. Last section is conclusion.

\section{LITERATURE REVIEW}

\subsection{Human Capital Theory}

The human capital theory was firstly proposed by Schultz (1961) and later developed extensively by Becker (1964) in early sixties due to realization that the growth of physical capital only plays small roles in growth of total income as compared to human capital.

Human capital theory suggests that level of productivity of the workers can be increase by education and training and hence, their income (Becker, 1964). Not only workers, this theory also can be used to justify the occupational wage differential between directors. Becker (1964) views human capital similar to "physical means of production" such as factory and machines. Investment in machine and technology will result in more quantity and quality of output. Similarly investment in education will enhance individual knowledge, expertise and skill. The organization that spend more money in training will collect their human capital investment via better productivity, creativity, less error and wastage and higher value of intellectual capital assets while for workers, their return on this investment is earned via higher wages and salary, promotion and advanced career ladder.

In essence, human capital theory implicitly believes that there is a "true value" for remuneration, captured in some way by using market force or human capital (Bender, 2003). It provides signal to the employer that the prospective employee are competent and able to deliver whatever tasks that they required to do by their employer. Thus, human capital theory can be be used to justify that directors' remuneration is determined not solely on the job itself but rather incorporates the human capital traits that he or she owns. For example, Agrawal (1981) found that director with greater amount of human capital has an ability to perform and provide a good result to the company. Thus, this type of director needs to be paid higher remuneration to motivate and retain them in the organization.

\subsection{Director's remuneration development in Malaysia}

Generally the focus on director remuneration in Malaysia is started after the Asian economic crisis in 1997. The government has taken major steps in improving the 
foundation of corporate governance by introducing Malaysia Code of Corporate Governance (MCCG) in 2000 aims to strengthen the corporate governance structure in the organization including reformation of regulations and guideline of directors' remuneration, training and education.

MCCG required that company need to remunerate their directors up to the level when their directors are inspired to manage the company successfully and achieved its objective. In case for inside directors, their remuneration should link with both individual and corporate performance such as profitability, growth and shareholders return. For outside directors, experience and level of responsibility become the basis for the level of remuneration. To further manage directors' remuneration efficiently and effectively, it is recommended for the company to establish remuneration committee that comprise at least mainly non-executive directors with the function to scrutinise and recommended the board the right remuneration package for each director. This can be done via a formal remuneration policy to ensure the remuneration process of the company is transparent. In term of disclosure, MCCG requires company to disclose details remuneration of individual directors in the annual report.

\subsection{Previous Studies on Director's Remuneration and Human Capital}

Directors' remuneration topic received wide interest among scholars from various discipline around the world starting from early 1960s. Most of the research are coming from the developed countries such as United States (US), United Kingdom (UK), France, Canada, Germany and other European countries. Ewers (2002) found that frequent terms used by previous studies are directors' remuneration, board remuneration, managerial remuneration, directors' compensation, CEO compensation, executive compensation, directors' pay and executive pay.

In the earlier stage of the study, the scholars try to relate director's remuneration with corporate performance (Marris, 1963) and later with the firm size (Williamson, 1964). There are also studies that examine other influential variables such diversification, risk and industry classification in order to improve the explanation on directors' remuneration (Balkin and Gomez-Mejia, 1990; Murphy, 2000).

The scholars then shift study focus on the relationship between corporate governance mechanism and directors' remuneration. Core et. al (1999), Boyd (1994), Conyon (1997) and Bryan et al. (2000) for example look at the board characteristics and ownership structure and its link with directors' remuneration. The swift interest in corporate governance mechanism is due to corporate scandals and mismanagement of the company around the world. The new governance requirement particularly on disclosures transparency imposed on the firms is likely to have an impact towards the director's remuneration level. 
In the UK for example, Bender (2003) found that the number of studies on director's remuneration only capture the scholars' interest when public are very concern at cases of poor integrity due to the collapse of BCCI Bank, Polly Peck and excessive pay or "fat cat" awards to executive directors. Due to this, there are numbers of report were published in UK to deal with this issue such as Cadbury Committee Report (1992), Greenbury Committee Report (1995) and Hampel Committee Report (1998).

The studies on remuneration are relatively new in the developing countries such as Malaysia, Singapore, India and China. The lacks of information available to the public due to poor transparency practices (Jaafar et al., 2014) also dominate these countries. The interests on this subject matter only rise immediately after financial economic crisis in 1997 that exposed a weak governance structure exercise by the company. India was among the first developing countries that take corrective action such as introduced code of corporate governance in 1998, followed by Malaysia and Singapore in 1999 and China in 2001. Most of the studies in the developing countries afterwards started to put greater importance on governance including directors' remuneration during and after that period. At the initial stage, most of the studies focus on firm performance as one of the explaining factor on directors' remuneration. Other variables such as firm size, type of industry, firm risk and firm value were added as control variables for most of the studies.

In Malaysia, few studies were conducted to examine the directors' remuneration level. Dogan and Smyth (2002) in their study on Malaysian listed companies found that there are positive relationship between board remuneration and sales turnover but negative relationship with ownership concentration. Hassan et. al. (2003) found a weak positive relationship between performance and director remuneration before and during the Asian financial crisis. The study also found that there is an increasing amount of directors' remuneration during that period although the return on equity (ROE) is decreasing, suggest that the director getting an increase in their remuneration at the expense of the shareholders' return. In more recent study, Jaafar et al. (2012) found that a relationship between director remuneration and performance is significantly positive among Malaysian family firms and directors in this type of firms are more willing to accept lower bonus to maintain healthy cashflow (Jaafar and James, 2014). In banking sector, Lee and Isa (2014) also find similar findings on the relationship between directors' remuneration and banks performance.

However, the study done by Abdullah (2006) using a distress and non-distress listed firms for the year 2001 and 2002 found that return on assets (ROA) is not associated with the directors' remuneration while board independent is negatively related to the level of directors' remuneration, indicates board independent effectively constrain the level of directors' remuneration. They also conclude that the firm growth and size is important in determining directors' remuneration. The mixed result in this study is due to the low level of awareness among company on the need to link the directors' 
remuneration with firms' performance during the period of the study. This findings supported by Minhat and Abdullah (2014) that found pay-performance relationship not applicable for government controlled firm as their executives were guaranteed certain level of remuneration regardless of performance.

The study related to human capital and remuneration initiated by Agrawal (1981). He suggests that level of reward received by the person should be based on their human capital attribute because individual with high human capital attributes is more efficient and productive. His argument was empirically supported by Murphy (1985), Tosi and Gomez-Mejia (1989) and McKnight and Tomkins (2004).

However, there are mixed result with regards to human capital attributes for both directors' age and tenure. Ingham and Thomson (1995) and Hogan and McPheters (1980) reported a positive influence of directors' age on CEO remuneration. In contrast, McKnight and Tomkins (2004) found weak influence of directors' age on remuneration

Deckop (1988) claimed executive tenure was a significant variable in determining total executive pay, whereas Randoy and Nielsen (2002), Hill and Phan (1991) and Hambrick and Finkelstein (1995) found no association between these variables. Hill and Phan (1991) argue that through increased tenure the CEO may gain control over the pay setting process and in turn design remuneration schemes to his or her preference. From the literature, it was found that human capital attributes were not examined extensively in previous studies. Thus, the findings of this study would therefore contribute the gap in the literature.

\section{HYPHOTHESES DEVELOPMENT}

\subsection{Directors' age}

Age is one aspect of human capital attributes that reflects experience and expertise of a person. Becker (1964) states that older individual would be exposed to various training, seminar and courses. In addition, they also more experienced and largely exposed in solving various business problems, handling management crisis and making corporate decision. Their human capital value will be accumulated through years of work (Guillet et al., 2012). Thus their level of experience, knowledge, productivity and skills is relatively higher than younger individual. Hence, the remuneration received by older directors supposed to be higher compare with younger directors. The additional experience contribute to more effective monitoring by directors and better firm performance (Doucouliagos et. al., 2007). In study done by McKnight and Tomkins (2004), they found that age have an influence on directors attitudes towards risk. The study suggests that younger individuals are more ready to accept risk compare with 
older individual that may lead to wrong investment decision. In addition, prior research suggests that age maybe related to corporate growth (Child, 1974), strategic decisions (Wiersema and Bantel, 1992) and remuneration decisions (Hitt and Barr, 1989). Hogan and McPheters (1980), Ingham and Thomson (1995) and Doucouliagos et al. (2007) found that there are positive relationship between directors' age and CEO remuneration level. Based on this findings, the following hypothesis is developed:

\section{H1: There is a relationship between directors' age and directors' remuneration}

\subsection{Directors' tenure}

Another aspect of human capital attributes is tenure. Long tenure in the company can be related to high level of expertise and experience of a person. In addition, long tenure will give director ample time to build their reputation and develop good relationships with key individuals from inside and outside the firm. This allows director to gain more respect, confidence and influence of the board members and induce them to award more compensation (Ryan and Wiggins, 2001). Loyalty also is another aspect that relate with tenure in which superior compensation is demanded as pay off of not moving to another organization. Hence, it is believe that the director may influence the board members to be more sympathetic towards their views.

Hill and Phan (1991) suggest that director that had served longer in the company able to influence board members to structure compensation package based on their opinion and choice. Deckop (1988), Kato (1997), Mangel and Singh (1993), Ghosh (2006), Li et al. (2007) and Abed et al. (2014) found that tenure was a significant variable in determining total executive pay while Guillet et al. (2012) finds that executives' compensation in the restaurant industry partly determined by tenure. Minhat and Abdullah (2014) documented that executive in government-controlled firms have a shorter tenure and as a result, earned lower payment. The next hypothesis is:

H2: There is a relationship between average directors' tenure on the board and directors' remuneration

\subsection{Directors' qualification}

Qualification refers to the level of education background of the individual. In general, qualification reflects the capability of the individual to perform their tasks. Moreover, qualification is an important indicator to employer to hire a prospective employee, including director of the company. Better qualifications indicate better knowledge, and therefore should bring difference in compensation (Gray and Benson, 2003). Datta and Iskandar Datta (2014) for example found that Chief Financial Officers (CFOs) with MBA received salary higher than CFOs without MBA while Bugeja et al. (2012) found that directors with strong skill and knowledge in takeover deal will be positively 
compensated in merger and acquisition process. In China, Chen and Ezzamel (2011) found that level of education that represents the prestige power of executive significantly positively related to executive remuneration while a study on Malaysian government link companies shows that executive receive low remuneration due to low level of education (Minhat and Abdullah, 2014). Hence, the following non direction hypothesis as follow is being developed:

H3: There is a relationship between directors' qualification and directors' remuneration

\section{RESEARCH METHODOLOGY}

\subsection{Sample Selection}

This study focuses on public listed companies in Malaysia and utilise secondary data that are available from companies' annual reports in 2012. This method enables the results to be generalizable, provided the sample size is sufficiently large. In 2012, there are total of 902 companies listed in main board. The study excluded 34 financial and investment related companies since the company are subjected specific regulations and monitoring, reducing the total population to 868 companies.

Table 1: Sample Size Based on Industry Classification

\begin{tabular}{lccc}
\hline \multirow{2}{*}{\multicolumn{1}{c}{ Industry }} & \multicolumn{2}{c}{ Size } & \multirow{2}{*}{ Percentage } \\
\cline { 2 - 3 } & Population & Sample & \\
\hline Trading \& Services/ Technology & 288 & 144 & $50 \%$ \\
Industrial Product & 268 & 134 & $50 \%$ \\
Consumer Product & 136 & 68 & $50 \%$ \\
Property/Hotel/Plantation/Mining & 128 & 64 & $50 \%$ \\
Construction/IPC & 48 & 24 & $50 \%$ \\
Total & 868 & 434 & $50 \%$ \\
\hline \hline
\end{tabular}

The stratified random sampling technique used in this study to ensure the results based on the sample can represent all type of industries in Malaysia. The samples were classified into five main industry group (Table 1) and then fifty per cent (50\%) of companies in each group are selected randomly from the listing. The final samples of the study were 434 companies.

\subsection{Dependent Variable: Directors' Remuneration}

Directors' remuneration in this study is based on the total remuneration for executive directors (Totalrem) which comprise of salary, bonus, fees and benefits excluding shares options. Share options or market based incentives are excluded from this study since the 
inconsistence format of reporting among the sampled firms as well as the details of reports varies across the firms making impossible for data collection. In order to avoid missing and inaccurate data, market based incentive are excluded from the study.

\subsection{Independent Variables: Human Capital Attributes}

Human capital attributes for directors are represented by age, tenure and qualifications. Previous studies on human capital look at the CEO age, tenure and qualifications only (Ingham and Thomson, 1995; McKnights and Tomkins, 2004). On this study, Age is defined as average age of executive directors (Total age of all executive directors/ Number of executive directors), tenure is defined as average tenure of all executive directors (Total tenure of all executive directors/ Number of executive directors) and qualification is measured by dummy variable which equals to one (1) if the executive is university graduates holder and zero (0) if otherwise.

\subsection{Regression Model}

This study seeks to develop a model that able to explain level of executive directors' remuneration among Malaysian listed firms. In particular, this model will explain the impact of human capital attributes towards directors' remuneration. In order to test the hypotheses, the following model is used:

$$
\text { LNtotalrem }=a+\beta_{1} \text { Tenure }+\beta_{2} \text { Age }+\beta_{3} \text { Qualification }+\mu
$$

where:

Totalrem $\quad=$ Total aggregate remuneration received by directors' in a firm

Tenure $\quad=$ Average directors' tenure on the board

Age $\quad=$ Average directors' age

Qualification $=$ Level of each director's qualification classified as graduate (including post graduate and professional qualification) (1) and non-graduates $(0)$

\section{FINDINGS AND DISCUSSION}

\subsection{Descriptive Analysis}

Table 2 shows the descriptive statistics of the dependent (total remuneration) and independent (human capital attributes) variables. The mean value for directors' remuneration is RM 2,691,102.78 whereas the minimum and maximum value for the directors' remuneration is RM 144,200 and RM 16,534,000 respectively. 
Table 2: Descriptive Statistics

\begin{tabular}{lccccc}
\hline \hline & $\begin{array}{c}\text { No. of } \\
\text { companies }\end{array}$ & Minimum & Maximum & Mean & Std. deviation \\
\hline Total remuneration & 434 & RM144,200 & RM16,534,000 & RM2,691,102 & RM2,055,093 \\
Average age & 434 & 42 years & 75 years & 56.99 years & 4.351 years \\
Average tenure & 434 & 1 year & 26 years & 8.39 years & 3.150 years \\
\hline \hline
\end{tabular}

The mean of directors' age for 2012 is 57 years. This finding is nearly similar with McKnight and Tomkins (2004), where the mean age of directors in the UK is found to be 55 years. Further examination revealed that majority or $71.9 \%$ of company directors fall under range 51-60 years old average age. However, big difference is found for the range of directors' age in Malaysia and the UK. The minimum age of directors is 26 years old and the maximum age of directors is 88 years old. In contrast, McKnight and Tomkins (2004) reported that the minimum and maximum age of directors in their sampled firms are 40 and 69 years old respectively. This wide range of directors' age in Malaysia may possibly due to high concentrated ownership of the sampled companies. Most directors tend to hold its position as long as possible from retirement while at the same time appoint their young family members to be part of the board of directors at the early age or after finished university’s education. In addition, Malaysia has limited pool of expertise to become directors of the companies. This is evident with the large number of old directors and busy directors in Malaysia.

In term year of service, directors' tenure average mean in 2012 is 8 years. Detail examination shows that the minimum tenure in the company is one (1) year and the maximum tenure in the company board of directors is 40 years. The longer tenure of directors in the company possibly due to several reasons, firstly, most of board member is the founder of the company. With that reasons, they hold majority shareholding in the company and have the voting right to retain their position in the board. Secondly, long tenure is related to high experience, expertise and proven track record. Due to this they remain in the board of directors for the longer period of time.

Table 3: Descriptive Statistics for Director's Level of Qualification

\begin{tabular}{lcc}
\hline \hline & No. of directors & \% of directors \\
\hline Non-university graduates & 313 & $10.3 \%$ \\
University graduates or professionally qualified & 2731 & $89.7 \%$ \\
Total & 3044 & $100 \%$ \\
\hline
\end{tabular}

For qualifications, Table 3 shows that $89.7 \%$ of the directors obtained university or professional qualifications. It shows that most of the director of the company is well educated and have capability to direct the company. This phenomenon is common in developing countries including Malaysia. 


\subsection{Correlation Analysis}

Normality test was conducted to ensure the data is normally distributed and met the condition to perform Pearson correlation and thereafter regression analysis. The assumption of normality, linearity and homoscedasticity were conducted and found to be supported. For example, all variables were found to have skewness between -2 and +2 (total remuneration:-.363, age: -.020, tenure: .900, qualification: .358) shows that all variables are normally distributed (Tabachnick and Fidell, 2013). In addition, visual inspection of the normal Q-Q plots for each variable confirmed that both were normally distributed. The inspection of a scatterplot of independent variables against the dependent variables confirmed that the relationship between these variables was linear and heteroscedastic.

Table 4: Pearson's Correlation Matrix for Explanatory Variables

\begin{tabular}{lcccc}
\hline \hline & Total Remuneration & Age & Tenure & Qualification \\
\hline Total Remuneration & 1 & & & \\
Age & $.120^{*}$ & 1 & & \\
Tenure & $.131^{* *}$ & $.125^{* *}$ & 1 & \\
Qualification & .049 & -.001 & $-.123^{*}$ & 1 \\
\hline \hline
\end{tabular}

Notes: *. Correlation is significant at the 0.05 level (2-tailed). ${ }^{* *}$. Correlation is significant at the 0.01 level (2-tailed).

Based on Table 4, the overall correlations among the variables were relatively low or medium and below 0.5. Even though the weak correlation recorded total remuneration with age $(r=.131, n=434, p<.005)$ and tenure $(r=.125, n=434, p<.01)$ it still shows positive correlation with $5 \%$ and $1 \%$ significant level respectively, shows that older directors and longer year of service by director in particular company will influence their remunerations. Directors' qualification (Qualification) however does not significantly correlate with total remuneration. Table 4 also shows that there is no multicollinearity issue since correlation between independent variables shows below 0.9 (Pallant, 2010).

\subsection{Regression Analysis}

The study aims to explore the impact of human capital attributes on directors' remuneration. Thus, Ordinary Least Square (OLS) regression analysis is conducted as the correlation coefficient alone is insufficient to test the existence of the influence by the independent variables. Multivariate analysis is perform to examine the extant independent variables interact with dependent variable. Multiple regressions are used to analyse the relationship between independent variables and dependent variable. 
Table 5: Regression Results for the Total Remuneration and Human Capital Attributes

\begin{tabular}{cccccc}
\hline \hline \multirow{2}{*}{ Variables } & \multicolumn{2}{c}{$\begin{array}{c}\text { Unstandardized } \\
\text { Coefficients }\end{array}$} & $\begin{array}{c}\text { Standardized } \\
\text { Coefficients }\end{array}$ & \multicolumn{2}{c}{$\begin{array}{c}\text { Collinearity } \\
\text { Statistics }\end{array}$} \\
\cline { 2 - 6 } & $\mathbf{B}$ & SE B & $\boldsymbol{\beta}$ & Tolerance & VIF \\
\hline (Constant) & 13.721 & .270 & & & \\
Age & .149 & .068 & $.105^{*}$ & .984 & 1.016 \\
Tenure & .029 & .011 & $.126^{* *}$ & .969 & 1.032 \\
Qualification & .303 & .225 & .064 & .985 & 1.016 \\
\hline \hline
\end{tabular}

Notes: $\mathrm{R}^{2}=0.032$, Adjusted $\mathrm{R}^{2}=0.026, \mathrm{~F}(4,430)=4.789, \mathrm{~N}=434, \mathrm{p}=.003 .{ }^{* *} \mathrm{p}<0.01 * \mathrm{p}<0.05$.

Table 5 shows the relationship between total remuneration with human capital attributes namely age, tenure and qualification. As can be seen, the $R^{2}$ and Adjusted $R^{2}$ is relatively low of $3.2 \%$ and $2.6 \%$ respectively. However, the model still fit for analysis because significant relationship may still exists between the dependent variables and independent variables even when the $R^{2}$ is low. Therefore, from the overall findings, it implies that 3.2\% of variation of total remuneration explained by variation in the human capital attributes $\left(R^{2}=0.032\right.$, adjusted $\left.R^{2}=0.026, F(4,430)=4.79, p=.003\right)$. All the variables have a tolerance of more than 0.1 and VIF of less than 5 , confirming the previous correlation analysis result that multicollinearity does not exist in the model, suggesting that the latent variables have adequate discriminant validity.

This study found that Age is positively related with total remuneration at $5 \%$ significant level, accepting $\mathrm{H} 1(\beta=.105, p<.05)$. This indicates that age of directors is positively related with total remuneration paid to the directors in the company. The result suggests that age is important in determining factor to the remuneration paid to the directors. This finding is consistent with the literature, for instance McKnight and Tomkins (2004), Ingham and Thomson (1995) and Doucouliagos et al. (2007). All the study reported a positive influence of directors' age with the remuneration paid to directors. This finding also can be supported by research done by Becker (1964) where he find that older directors would be much more exposed to various training that raises their knowledge, productivity and skills. Thus it will be reflected in their level of pay received by the company.

Tenure also positively related with total remuneration at $1 \%$ significant level accepting $\mathrm{H} 2(\beta=.126, p<.01)$. It suggest that tenure of directors influence the level of pay to the directors of the company. Long tenure can be related to high experience and proven track records of directors in the company. Hence with high level of expertise the directors able to earn higher remuneration from the company. The finding is consistent with McKnight and Tomkins (2004), Deckop (1988), Kato (1997), Mangel and Singh (1993), Ghosh (2006), Li et al. (2007), Guillet et al. (2012), Abed et al. (2014) and Minhat and Abdullah (2014). They argued that increased in directors' tenure enable them to exercise influence over the board's decision, provide enough time for them to 
acquire respect and confidence over the board members. Hence, this factor therefore will increase the directors' remuneration pays to directors of the company.

Directors' qualification (Qualification) however shows no significant relationship with remuneration, rejecting H3. This indicates that the level of directors' remuneration is no longer related to their level of qualification. This may due to the reason that at the directors' level, working experience, skills and proven track record is more important than their level of qualification. Although director have higher qualification, this attributes is meaningless if it cannot be applied and translated with a superior performance and good contribution. It also implies that theoretical knowledge acquired during the process to obtain such qualifications is less appreciated with applied or practical knowledge exercise by the director. With no previous literature found for interaction between these two variables, this result may contribute to literature for future.

\section{CONCLUSIONS}

This study focus on three types of human capital attributes namely age, tenure and qualification and its impact on directors' remuneration. All the hypotheses predicted that all these attributes has a relationship with directors' remuneration. It was found that only age and tenure have significant positive relationship with total remuneration. Thus, it can be concluded that human capital theory did apply in Malaysian business environment particularly in directors' remuneration context.

The study however has identified several limitations that also become the opportunity for the future research. Firstly, this research has excluded of stock options from calculation of total directors' remuneration. This is due to inconsistent reporting and valuation of options among Malaysian firms in their annual report. From our finding, there are only few firms choose to report in detail on stock options in their annual reports. Thus unless the requirement or standards is imposed for all firms to disclose the information on stock option owned by managers, the exclusion of stock options from directors' remuneration is here to stay.

This study also excludes the foreign-owned firms from the sample. Future research should include foreign firms in order to see further understands the effect of human capital attributes on directors remuneration. Future studies also can extend the number of observation years in order to provide better result and can be generalized.

Finally, data only collected in one particular year. Future research should be conducted by employing many years of data collection to ensure the result is more robust and thorough. 


\section{REFERENCES}

Abdullah, S. N. (2006). Directors' remuneration, firm's performance and corporate governance in Malaysia among distressed companies. Corporate Governance, 6(2), 162-175.

Abed, S., Suwaidan, M., \& Slimani, S. (2014). The determinants of chief executive officer compensation in Jordanian industrial corporations. International Journal of Economics and Finance, 6(12), 110-118.

Agrawal, N. C. (1981). Determinants of executive compensation. Industrial Relations, 20(1), 36-45.

Balkin, D. B., \& Gomez-Mejia, L. R. (1990). Matching compensation and organizational strategies. Strategic Management Journal, 11(2), 153-169.

Beatty, R. P., \& Zajac, E. J. (1994). Top management incentives, monitoring, and risk sharing: A study of executive compensation, ownership and board structure in initial public offerings. Administrative Science Quarterly, 39(2), 313-336.

Becker, G. S. (1964). Human capital: A theoretical and empirical analysis, with special reference to education. New York: National Bureau of Economic Research.

Bender, R. (2003). How executive directors' remuneration is determined in two FTSE 350 utilities. Corporate Governance, 11(3), 206-217.

Boyd, B. K. (1994). Board control and CEO compensation. Strategic Management Journal, 15(5), 335-344.

Bryan, S. H., Hwang, L., Klein, A., \& Lilien, S. B. (2000). Compensation of outside directors: An empirical analysis of economic determinants. Accounting Working Papers, New York University.

Bugeja, M., da Silva-Rosa, R., Duong, L., \& Izan, H. Y. (2012). CEO compensation from M\&As in Australia. Journal of Business Finance \& Accounting, 39(9-10), 1298-1329.

Cadbury Committee Report. (1992). Committee on the financial aspects of corporate governance. London: Gee.

Chen, J., Ezzamel, M., \& Cai, Z. (2011). Managerial power theory, tournament theory, and executive pay in China. Journal of Corporate Finance, 17(4), 1176-1199.

Cheng, S., \& Firth, M. (2006). Family ownership, corporate governance, and top executive compensation. Managerial \& Decision Economics, 27(7), 549-561.

Child, J. (1974). Managerial and organizational factors associated with company performance part I. Journal of Management Studies, 11(3), 175-189.

Conyon, M. J. (1997). Corporate governance and executive compensation. International Journal of Industrial Organization, 15(4), 493-509.

Conyon, M. J., \& He, L. (2011). Executive compensation and corporate governance in China. Journal of Corporate Finance, 17(4), 1158-1175.

Conyon, M. J., \& Leech, D. (1994). Top pay, company performance and corporate governance. Oxford Bulletin of Economics and Statistics, 56(3), 229-247. 
Core, J., Holthausen, R., \& Larcker, D. (1999). Corporate governance, chief executive officer compensation and firm performance. Journal of Financial Economics, 51(3), 371-406.

Datta, S., \& Iskandar-Datta, M. (2014). Upper-echelon executive human capital and compensation: Generalist vs specialist skills. Strategic Management Journal, 35(2), 1853-1866.

Deckop, J. R. (1988). Determinants of chief executive officer compensation. Industrial and Labor Relations Review, 41(2), 215-226.

Dogan, E., \& Smyth, R. (2002). Board remuneration, company performance and ownership concentration: Evidence from publicly listed Malaysian companies. ASEAN Economic Bulletin, 19(3), 319-347.

Doucouliagos, H., Haman, J., \& Askary, S. (2007). Directors' remuneration and performance in Australian banking. Corporate Governance: An International Review, 15(6), 1363-1383.

Eisenhardt, K. M. (1989). Agency theory: An assessment and review. Academy of Management Review, 14(1), 57-74.

Eriksson, T. (2000). What determines managers' pay? Evidence from Denmark. Long Range Planning, 33(4), 544-559.

Ewers, D. (2002). Director remuneration and performance - A study of top UK Companies 1996-1998. London: Brunel University.

Fama, E. F. (1980). Agency problems and the theory of the firm. The Journal of Political Economy, 88(2), 288-307

Finance Committee on Corporate Governance. (2001). Malaysian code on corporate governance. Kuala Lumpur: Malaysian Institute of Corporate Governance.

Ghosh, A. (2006). Determination of executive compensation in an emerging economy: Evidence from India. Emerging Markets Finance and Trade, 42(3), 66-90.

Gray, S. R., \& Benson, P. G. (2003). Determinants of executive compensation in small business development centers. Nonprofit Management and Leadership, 13(3), 213-227.

Greenbury Committee Report. (1995). Directors' remuneration - Report of a study group chaired by Sir Richard Greenbury. London: Gee.

Gregg, P., Machin, S., \& Szymanski, S. (1993). The disappearing relationship between directors' pay and corporate performance. British Journal of Industrial Relations, 31(1), 1-10.

Guillet, B. D., Kucukusta, D., \& Xiao, Q. (2012). An examination of executive compensation in the restaurant industry. International Journal of Hospitality Management, 31(1), 86-95.

Hallock, K., \& Murphy, K. J. (1999). The economics of executive compensation. Cheltenham: Edward Elgar Pubishing Ltd.

Hambrick, D. C., \& Finkelstein, S. (1995). The effects of ownership structure on conditions at the top: The case of CEO pay rises. Strategic Management Journal, 16(3), 175-193. 
Hampel Committee Report. (1998). Committee on corporate governance - Final report. London: Gee.

Hassan, S., Christopher, T., \& Evans, R. (2003). Directors' remuneration and firm performance: Malaysian evidence. Malaysian Accounting Review, 2(1), 57-67.

Hill, C. W. L., \& Phan, P. (1991). CEO tenure as a determinant of CEO pay. Academy of Management Journal, 34(3), 707-717.

Hitt, M. A., \& Barr, S. H. (1989). Managerial selection decision models: Examination of configural cue processing. Journal of Applied Psychology, 74(1), 53-61.

Hogan, T. D., \& McPheters, L. R. (1980). Executive compensation: Performance versus personal characteristics. Southern Economic Journal, 46(4), 1060-1068.

Ingham, H., \& Thompson, S. (1995). Mutuality, performance and executive compensation. Oxford Bulletin of Economics and Statistics, 7(3), 295-308.

Jaafar, M. Y., Nawawi, A., \& Salin, A. S. A. P. (2014). Directors' remuneration disclosure and firm characteristics - Malaysian evidence. International Journal of Economics \& Management, 8(2), 269-293.

Jaafar, S. B., \& James, K. (2014). Director remuneration pay: Trends during and after the financial crisis of 2007 to 2009. Australasian Accounting, Business and Finance Journal, 8(3), 56-69.

Jaafar, S. B., Wahab, E. A. A., \& James, K. (2012). Director remuneration and performance in Malaysia family firms: An expropriation matter? World Review of Business Research, 2(4), 204-222.

Kato, T. (1997). Chief executive compensation and corporate groups in Japan: New evidence from micro data. International Journal of Industrial Organization, 15(4), 455-467

Lee, S. P., \& Isa, M. (2014). Directors' remuneration, governance and performance: The case of Malaysian banks. Managerial Finance, 41(1), 26-44.

Li, D., Moshirian, F., Nguyen, P., \& Tan, L. (2007). Corporate governance or globalization: What determines CEO compensation in China? Research in International Business and Finance, 21(1), 32-49.

Mangel, R., \& Singh, H. (1993). Ownership structure, board relationships and CEO compensation in large US corporations. Accounting and Business Research, 23(1), 339-350.

Marris, R. (1963). A model of the managerial enterprise. Journal of Economics, 77(2), 185-209.

McKnight, P., \& Tomkins, C. (2004). The implications of firm and individual characteristics on CEO pay. European Management Journal, 22(1), 27-40.

Mehran, H. (1995). Executive compensation structure, ownership and firm performance. Journal of Financial Economics, 38(2), 163-184.

Minhat, M., \& Abdullah, M. (2014). Executive compensation in government-linked companies: Evidence from Malaysia. Applied Economics, 46(16), 1861-1872.

Murphy, K. J. (1985). Corporate performance and managerial remuneration. Journal of Accounting and Economics, 7(1-3), 11-42. 
Murphy, K. J. (2000). Performance standards in incentive contracts. Journal of Accounting and Economics, 30(3), 245-278.

Pallant, J. (2010). SPSS survival manual: A step-by-step guide to data analysis using SPSS program ( $4^{\text {th }}$ edn). Berkshire: McGRaw-Hill.

Randoy, T., \& Nielsen, J. (2002). Company performance, corporate governance and CEO compensation in Norway and Sweden. Journal of Management and Governance, 6(1), 57-81.

Ryan, J. H. E., \& Wiggins, R. A. (2001). The influence of firm-and manager-specific characteristics on the structure of executive compensation. Journal of Corporate Finance, 7(2), 101-123.

Schultz, T. (1961). Investment in human capital. The American Economic Review, 51(1), 1-17.

Tabachnick, B. G., \& Fidell, L. S. (2013). Using multivariate statistics ( $6^{\text {th }}$ edn). Boston: Pearson Education

Tosi, H. L., \& Gomez-Mejia, L. R. (1989). The decoupling of CEO pay and performance: An agency theory perspective. Administrative Science Quarterly, 34(2), 169-189.

Wiersema, M. F., \& Bantel, K. A. (1992). Top management team demography and corporate strategic change. Academy of Management Journal, 35(1), 91-121.

Williamson, O. (1964). The economics of discretionary behaviour: Managerial objectives in a theory of the firm. Englewood Cliffs, NJ: Prentice Hall.

Yermack D. 1995. Do corporations award CEO stock options effectively? Financial and Economic Journal, 39(3), 237-269. 